\title{
A Concept of WSD as an Implemented Approach to the Successful Design of a High-Rise Residential
}

\author{
Diah Listyaningsih ${ }^{1, *}$, and Christiono Utomo $^{1}$ \\ ${ }^{1}$ Sepuluh Nopember Institute of Technology Jl. Raya ITS, Keputih, Sukolilo, Kota SBY, Jawa Timur 60111, Indonesia
}

\begin{abstract}
Construction project success depends on success of design. It is very rare previous research about the success of design as a determinant to the success of construction projects. The Whole System Design (WSD) approach in a planning of a high-rise residential property consider the success interrelatedness of both problems and solutions. It can help to create more sustainable designs. Nevertheless, designers often face several factors that exclusively reduce the rate of successful design i.e. design model and methods. One way to manage this issue is to reduce ambiguousness by using a whole system design approach. This study purposes to explore framework of Whole System Design approach for successful design. Application of literature review method is used to understanding the problem by analysing 20 articles about high-rise building, residential and whole system design. The result presents a mapping of several methods that used in previous research. It is to help more widespread the successful design in a high-rise residential property.
\end{abstract}

\section{Introduction}

In a building project there are some problems on the life cycle project, that are design, construction, closing and operational process. A study [1] about residential buildings in Jakarta reveal that they are in slum condition because of the level of damage and quality deterioration of the building material and the level of building maintenance budget availability. The other example is in construction phase, there are some problem like project delay that caused by low productivity rates and cost overruns [2], there are complexity of the finishing works in high-rise apartment. Sack and Goldin [3] explains that the complexity for execution finishing works in high-rise building is made complex by the need to customize apartment to the varying requirements and designs of individual clients. In the closing process when the product or project deliver to the customer, the important factors in a house purchase decision is the location of the property and the price [4]. In Hong Kong [5], Green labelling on residential property suspected be one of the importance choice in purchase of property. People are willing to pay more for green building recognized by HK-BEAM and HK-GBC. Chan and Chen [6] compare the high house prices in Sydney and in Taipei by high property taxes and fees, but the result of cutting property taxes and fee may not solve the problem. There are stable long-run relationships between construction output and property price for both housing and retail construction sectors [7].

There is one approach that used for planning process to achieve a sustainable building used WSD [8]. The approach encourages the development of partnerships between actors from a variety of different backgrounds, disciplines and sectors to develop an innovative, sustainable and optimised solution at a whole system level.

This research use literature review method and focus on leading journals that publish research of highrise building, residential and WSD. The target of this literature is following journals: Journal of Development and Management, Design Studies, Journal of Civil Engineering and Management, Evaluation of Program Planning, Property Management, Journal of Facilities Management, International Journal of Project Management, Built environment project and asset management.

This research purpose to get several methods to help more widespread the successful design in a highrise residential property by explore framework of Whole System Design approach for successful design. Step by step approach to implementing process redesign is critical to the effort. So, the successful design and construction framework of the reengineering solution should be created [9].

\section{Conceptual background}

Main reasons of using WSD approach in high-rise residential building are to create more systemic and sustainable solutions from stakeholder's perspective [10], to provides designers with necessary knowledge to more effectively work within, to manage and facilitate design process [11] and to reduce ambiguity in the whole systems approach with knowing the guiding processes, principles, and methods of sustainable design as defined

\footnotetext{
* Corresponding author: diah.listyaningsih@gmail.com
} 
by various design disciplines and how that is applicable for sustainable design across all disciplines [12]. It would be easier to solve the problem in design with WSD approach by reduce ambiguity of the problem and the solve.

WSD is a tool that is used to combine the entire system design and foundation for holistic action [8]. In whole system thinking, problems are made by each part of the system and can be handled by each part of the system [13]. In this whole system thinking, the approach focuses more on the interaction of each system to change a system itself, they seek common solutions to solve many problems.

There are some programs to solve the problem in whole system [13], that are: combining system thinking into design, support using economic and environmental tools, fix the standardize and apply metric for programmed interventions, creating awareness of sustainable investment as a necessary of sustainable production and practice. [11] purposes factors that influence of WSD success into eight factor. That are effective partnership, communication, individuals should have the skills and interest to learn more, understand the purpose, alignment of interest, simplify the design complexity, WSD facilitator, and integration between all systems.

Some studies about WSD has conducted to explore the element and factor of it [10], [11], [12]. Other study discusses about application a factor in real project i.e.: communication [14], and system thinking [15], [16].

\section{Result and Discussion}

\subsection{Methodology}

It is found 20 articles that considered to be suitable with the topic. The previous study was relatively related with high-rise residential, while not many articles study about Whole System Design. The literature on high-rise building has grown quite steady, the literature discussing in a design context is very different. In life cycle project, the researches that study about design phase are still limited.

To determine the method that use on some researches, it drew a systematic literature review. A systematic literature review is a technique to get an overview of previous studies in systematic ways [17]. [10] conducted literature review to explore approaches to systemic design and sustainable solutions Likewise, [14] conducted literature review to summarize the existing literature and identify gaps in current then provide framework for future research. In this study, literature review use to find several methods from the papers.

To understand the methods that used in previous research, it categorized by 7 methods, that are: literature review; case study; IT model; statistical analysis; combine of literature review, survey, and statistical analysis; survey and statistical analysis; and interview and confirmatory.

To explore the method of 20 articles that have been reviewed, this paper will be analysed by grouping the data. This research mapping quadrant base on qualitative, quantitative, primary and secondary data.

\subsection{Result}

There is one approach that used for planning process to achieve a sustainable building used WSD. The approach encourages the development of partnerships between actors from a variety of different backgrounds, disciplines and sectors to develop an innovative, sustainable and optimised solution at a whole system level [8]. To understanding the process of WSD, [11] conducted a research using a case study. It found some factors influencing the success of WSD. By literature review, the other research present that there are elements of WSD identified in three phase: process, principles and methods. Table 1 present the element of WSD.

Table 1. The Elements of WSD [12], [8]

\begin{tabular}{|c|c|}
\hline Design Phase & Element of WSD \\
\hline \multirow{2}{*}{$\begin{array}{c}\text { Design } \\
\text { Objectives }\end{array}$} & $\begin{array}{c}\text { Establish common goal and define the } \\
\text { scope to make a good solution }\end{array}$ \\
\cline { 2 - 2 } $\begin{array}{c}\text { Design } \\
\text { Principles }\end{array}$ & Stakeholder satisfaction \\
\cline { 2 - 2 } & System thinking \\
\hline \multirow{4}{*}{$\begin{array}{c}\text { Concept of sustainability building } \\
\text { Process }\end{array}$} & Practice mutual learning \\
\cline { 2 - 2 } & Share all information \\
\cline { 2 - 2 } & Optimization energy and waste \\
\cline { 2 - 2 } & Optimization benefit and impact \\
\cline { 2 - 2 } & Think innovation technology \\
\cline { 2 - 2 } & $\begin{array}{c}\text { Benchmarking against the best practice } \\
\end{array}$ \\
\hline
\end{tabular}

Communication also has an important role of successful system design. Understanding the design is part of communication. By using Semantic analysis (LSA), [16] studied communication between design teams about structuring language. The result is the similarity using language does affect the level of understanding of the team towards design. [18] found the Daily System Meeting (DSM) is often use in the team, but in the practice, it turned out that DSM is not efficient because the frequency too high and the duration too long. it should be guidelines in the company to improve the way they conduct DSM to a better in daily work.

To avoid bias information, system thinking need to be implemented. Cabrera found DSRP (Distinction, System, Relationship, Perspectives) rules method use to applying simple rules based on patterns of thinking [9]. But, there are main barriers to adopting the system thinking. Based on interview with sixteen senior construction professionals with experience, that are conflicts of interest within PPP projects; the methods that used still traditional; do not want to change; lack of time and resources; perceptions of complexity; unknown legal implications of sharing risk, and practice of existing management [19]. Used system thinking not easy to do, because each individual is used to doing habits since a long time that not in line with it.

In line with [9], system thinking is use to sustainable solution. It makes innovative solution to meet customer 
needs. System thinking also related with explored the idea by case study of a professional design team's use of idea generation with analyses at five emergent timescales: look at the structure, the content, and the actions of the team at each level [20]. Another literature study found that framework for the successful design and construction [14].

Another factor that influencing WSD are back to nature and rethink waste with using energy efficient. There is study found that the energy consumption of construction plays a significant factor in the life cycle energy analysis of a building [21] and the other study found that implementation of energy audit could reduce the cost [22]. There are relationships between construction activity and property price, as investigated by [7] using autoregressive distributed lag (ADRL), a method for forecasting construction output. Used hedonic price model, [5] found that Green features have a significant relationship with residential property price. But, [4] try to gather the important factors by buyers in residential property market. The result is people not awarness yet about "green" and "energy efficient" residential property and they think that the important factors of buying the house are the location and the price. So, energy efficiency and back to nature, which is component of WSD, take effect to successful design but some people still not aware about that.

Furthermore, the researches mostly identify how to project success on construction phase, just a little that identify on the design process. For example, [23] found a method using the line-of-balance technique to implement this principle in the construction of high-rise apartment building projects. [24] using eTACT method for a highrise residential building to evaluates the time reduction. The result shows that finish work time was reduced faster than the schedule. Indeed, the research in construction phase is important, but it will be better if the design is properly. Then, the WSD factor explored by adopted of a qualitative, exploratory and inductive approach enabled the collection of amount of primary data as to what factors were most relevant [11]. The success design also considered the minimal waste resulting from the project construction. Monte Carlo simulation used to compare lean and non-lean of residential building project and the result is application of lean construction could improve the performance of the project [2], [3].

\subsection{Discussion}

The literature review mapping of implementation approach to the successful design of a high-rise residential properties is shown on Table 2.

Table 2. Literature Review Mapps of Previous Research Method

\begin{tabular}{|c|l|l|}
\hline No. & \multicolumn{1}{|c|}{ Method } & \multicolumn{1}{|c|}{ Previous Research } \\
\hline 1 & Literature review & {$[9],[11],[12],[15]$} \\
\hline 2 & Case study & $\begin{array}{l}{[10],[13],[14],[16],} \\
{[17],[18],[19],[21]}\end{array}$ \\
\hline 3 & IT Model & $\begin{array}{l}{[3]: \text { Lean Management }} \\
\text { Model }\end{array}$ \\
\hline
\end{tabular}

\begin{tabular}{|c|l|l|}
\hline No. & \multicolumn{1}{|c|}{ Method } & \multicolumn{1}{c|}{ Previous Research } \\
\hline 4 & Statistical analysis & $\begin{array}{l}\text { [2]: Monte carlo } \\
{[7]: \text { ADRL }}\end{array}$ \\
\hline 5 & $\begin{array}{l}\text { Literature review, } \\
\text { survey, statistical } \\
\text { analysis }\end{array}$ & {$[1]$} \\
\hline 6 & $\begin{array}{l}\text { Survey, Stastistical } \\
\text { analysis }\end{array}$ & $\begin{array}{l}{[4],[5]: \text { hedonic price }} \\
\text { model, [6], }\end{array}$ \\
\hline 7 & Interview, confirmatory & {$[20]$} \\
\hline
\end{tabular}

According to the mapping at the Table 2, there are two data sources, that are primary and secondary data collection. [25] generally classified the data into primary and secondary data collection. The primary data is collected by the author through observation, experimentation, survey, interview, diary method, case studies. The secondary data is collect base on someone else and there is a great deal available to you from books, libraries and on the web. Then the analysis method that used in previous research are quantitative and qualitative analysis [26]. Quantitative analysis is an interrelated set of constructs (or variables) formed into propositions, or hypotheses, that specify the relationship among variables (typically in terms of magnitude or direction) presented by statistic and other program to analyse the data. Qualitative analysis is providing a ready-made series of hypotheses to be tested from the literature. The diagram of the position each research literature shown on Picture 1.

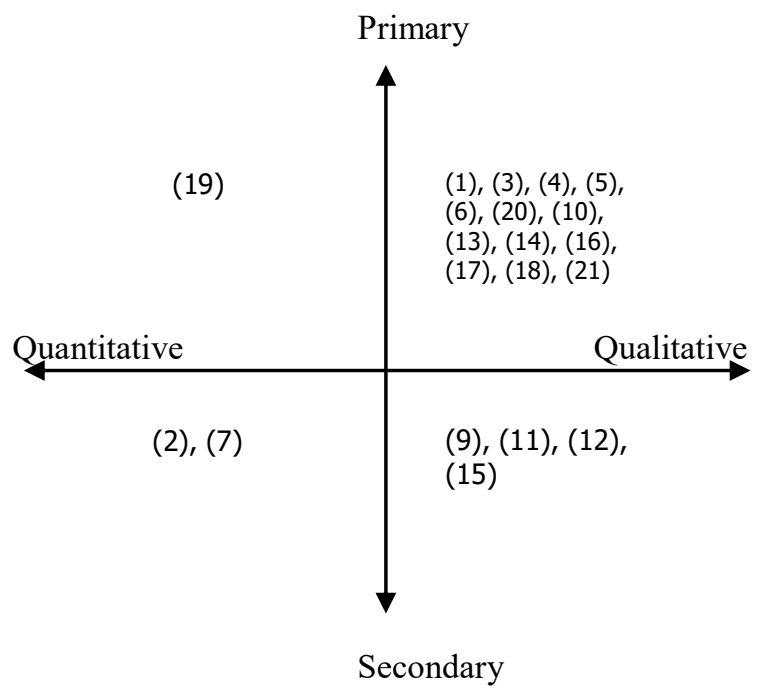

Fig. 1. Mapping diagram

Based on Fig. 1, the most method used is qualitative and primary data. Some data analysis used qualitative data analysis. The data collected from survey and interview with the professional worker in the project. Pulling the primary data may be easier than the secondary one because it is no need more time than literature review.

\section{Conclusion}


Base on the issues above, it can be concluded that the future research considers the qualitative primary method, which are doing by questionnaire or interview, then data will be analysed by statistic program. After exploring the literature, it has to provide a better understanding of the approach method mostly use to collect data. It results have also identified important questions for future research to find the variables of WSD.

The authors appreciate the recognition and awards in forms of research grant and fellowship from "Penelitian Berbasis Kompetensi 2018 based on contract number 836/PKS/ITS/2018”.

\section{References}

1. P. Arumsari, A.D. Rarasati, Built environment project and asset management, 7, 99-110 (2016)

2. H. Erol, I. Dikmen, M.T. Birgonul, JCEMt, 23, 241-251 (2017)

3. R. Sacks, M. Goldin, JCEM, 133 (2007)

4. C. Eves, S. Kippen, Property Management, 28 (2010)

5. Jayantha, Journal of Facilities Management (2013)

6. N. Chan, F. Chen, Property Management, 29 (2011)

7. X. Zeng, K.W. Chau, E.C. Hui, CME, 30 (2012)

8. P. Stasinopolous. M. Smith, K. Hargroves, C. Desha, Whole system design: An integrated approach to sustainable engineering, London : EarthScan (2009)
9. D. Cabrera, L. Colosi, C. Lobdell, Evaluation and Program Planning, 31, 299-310 (2008)

10. F.J.S. Coley, M.Lemon, Journal of Engineering Design, 20 (2009)

11. F. Charnley, M. Lemon, Design Studies, 32 (2011)

12. J.L. Blizzard, L.E. Klotz. Design Studies, 33 (2012)

13. J. W. Creswell, Qualitative, quantitative, and mixed methods approaches research design $4^{\text {th }} e d$, United States: Sage (2014)

14. M. Attaran, Journal of Management and Development, 19, 794-801 (2000)

15. S. Macmillan, J. Steele, S. Austin, R. Spence, P. Kirby, ICED, (1999)

16. A. Dong, Design Studies, 26, 445-461 (2005)

17. D. Tranfield, British Journal of Management, 14, 207-22 (2003)

18. R. Sacks, M. Goldin, JCEM, 133, 374-384 (2007)

19. M. Loosemore, E. Cheung, IJPM, 33, 1325-1334 (2015)

20. K. Shover, T. Lovins, J. Turns, M.E. Cardella, C.C. Atman, Design Studies 57, 9-36 (2018)

21. G. Ding, P.J. Forsythe, CME, 31, 445-461 (2013)

22. D. Bieksa, G. Siupsinskas, V. Martinaitis, E. Jaraminiene, JCEM, 17, 467-475 (2011)

23. C.G.D. Rocha, S. Kemmer, Jounal of CME (2013)

24. Lee, JCEM, 22, 944-953 (2016)

25. J. Adams, H.T.A. Khan, R. Raeside, D. White, Research methods for graduate business and social science students, New Delhi: Response Book (2007) 